\title{
Notas
}

\section{O domínio chinês sobre o Tibet}

\section{CARMEN LÍCIA PALAZZO-ALMEIDA}

A nação tibetana, atualmente incorporada à China, possui uma história que deve ser lembrada quando se trata de analisar a invasão chinesa de 1949 e a atual política de transferência de população e de sinização da cultura do Tibet. Os argumentos que o governo chinês utiliza para justificar o que se constitui em um verdadeiro ato de imperialismo não se sustentam historicamente. O mais frágil de todos e que evoca a triste lembrança da "missão civilizatória" dos europeus em séculos passados é aquele que alega a necessidade de interferência chinesa para levar o desenvolvimento a um povo que vivia oprimido pela religiosidade do budismo lamaísta. Os historiadores conhecem bem os argumentos franceses e belgas sobre a importância de estender a civilização à África e a evocação inglesa de que o homem branco levaria às colônias o desenvolvimento e a modernização. Foram sempre atos de violência que se seguiram à idéia de transformar o outro, de destruir crenças nativas, de considerar a religião e os costumes como dados culturais passíveis de homogeneização.

É importante, porém, ressaltar que a própria história invalida a afirmação de que o Tibet é parte da China. Quando, em 641, Songstem Gampo, o unificador de várias tribos na entidade política tibetana, casa-se com uma princesa chinesa da dinastia Tang, estreitam-se os contatos com o Império sem que, no entanto, fique evidente qualquer tipo de submissão. No século XII, os mongóis se expandem e conquistam a China, iniciando-se um relacionamento mais profundo com as populações dos Himalaias, envolvendo os mosteiros e a elite clerical budista. O Tibet entra numa fase de reconhecimento da suserania mongol, pagando com regularidade um tributo, mas mantendo intacta sua cultura e sua religião. ${ }^{1}$

Após a derrota dos mongóis na China, em meados do século XIV, a dinastia Ming pouco se interessa pelo Tibet. Nos séculos seguintes, afirma-se em Lhassa a seita dos Gelugpas, da qual saem os sucessivos Dalai Lamas e complica-se o relacionamento sino-tibetano. $\mathrm{O}$ jogo político na região leva à cooptação das lideranças religiosas envolvidas em um elaborado processo de sucessão baseado na crença da reencarnação. Toda a complexidade e os tortuosos meandros que caracterizam não apenas o relacionamento entre a China e o Tibet, mas também outras disputas regionais, tornam evidente que os tibetanos mantiveram, através 
dos séculos, uma existência própria, não chegando nunca a ter seu território, idioma ou população assimilados ao Império vizinho.

Quando, em 1788, tribos hindus atacam o Tibet, a China envia seus exércitos contra os invasores em uma operação de salvamento que representa um passo no sentido de impor um certo controle por parte de oficiais chineses na política interna tibetana. O que ocorre assemelha-se a outros exemplos históricos, nos quais a potência imperial se vale de uma posição de força para cobrar a interferência em troca de apoio militar. Mais adiante, no século XIX, os ingleses interessam-se pela região visando a possibilidade de abertura de uma rota comercial entre a Índia, o Tibet e Sichuan. Outro cenário se desenha então nos Himalaias, com a presença também de atores como a Índia e a Rússia. A produção e a distribuição do chá se constitui em um dos principais motivos de disputa, além das rivalidades de caráter político que levam a enfrentamentos entre as potências pelo domínio de territórios asiáticos. No século XX, com a invasão de 1949, o governo comunista reafirma uma vontade imperialista que já havia sido tentada em outras oportunidades e em outros contextos na mesma região.

Discorrer sobre a movimentada história tibetana no decorrer de vários séculos demandaria longas explanações para iluminar uma grande riqueza de detalhes, o que não cabe no escopo da presente nota. O que se pretende, no entanto, é salientar o fato de que o Tibet não constitui uma parte da China, evidência que se faz clara também através da constatação de uma significativa homogeneidade religiosa, lingüística e étnica da nação tibetana.

Atualmente, várias tentativas têm sido feitas, em termos de negociações pragmáticas, para chegar a um resultado que seja aceito por ambas as partes. Em 1979, Gyalo Thondup, irmão mais velho do Dalai Lama, esteve com Deng Xiaoping e recebeu informações de que, fora a independência, outras soluções poderiam ser discutidas. Até 1988, manteve-se a esperança de um diálogo que talvez pudesse ser favorável à preservação da língua e da cultura do Tibet. Contudo, em seguida, as relações se deterioraram, culminando, em 1995, com a tentativa chinesa de usurpar aos tibetanos o direito de escolha de uma de suas mais importantes figuras religiosas, o Panchen Lama.

Mais acentuadamente desde 1998, o governo tibetano no exílio, instalado em Dharamsala na Índia, se dispõe a negociar saídas que não sejam a total independência, pois, o Dalai Lama está consciente de que não contará com o apoio de nenhuma potência em sua cruzada contra os invasores. Dificilmente algum país se arriscará a enfrentar a China no momento em que esta se abre ao exterior como um promissor parceiro comercial. Em algumas reuniões internacionais, na imprensa européia e norte-americana e no âmbito de Organizações NãoGovernamentais surgem diversas vozes de repúdio à atitude chinesa sem que, no entanto, este repúdio se concretize em medidas de caráter prático. ${ }^{2}$ 
Enquanto isso, prossegue a política de sinização através do incentivo econômico à emigração de chineses para o Tibet. A maciça transferência populacional é talvez o passo mais eficiente e mais perverso no projeto de aniquilação da cultura tibetana.

Junho de 2000

\section{Notas}

1 Sobre a história do Tibet, ver WALT VAN PRAAG, Michael C. van. The Status of Tibet: History, Rights and Prospects in International Law. Boulder: Westview Press, 1987.

2 O site do governo tibetano no exílio permite que se tenha acesso a uma documentação importante, incluindo a correspondência entre autoridades tibetanas a chinesas. Ver http://www.tibet.com 